\title{
Erratum to: "Neuropeptide S receptor 1 (NPSR1) activates cancer-related pathways and is widely expressed in neuroendocrine tumors
}

\author{
V. Pulkkinen • S. Ezer • L. Sundman • J. Hagström • \\ S. Remes • C. Söderhäll • D. Greco • C. Haglund • \\ J. Kere • J. Arola
}

Published online: 3 July 2014

(C) Springer-Verlag Berlin Heidelberg 2014

\section{Erratum to: The European Journal of Pathology}

DOI: 10.1007/s00428-014-1602-x

The authors regret that an error occurred in the name of the 7th listed co-author for this paper. G. Dario was listed in the original paper instead of $\mathrm{D}$. Greco. The correct listing can be seen above.

The online version of the original article can be found at http://dx.doi.org/ 10.1007/s00428-014-1602-x.

V. Pulkkinen

Pulmonary Division, Department of Medicine, University of

Helsinki, Helsinki, Finland

S. Ezer $\cdot$ L. Sundman $\cdot$ J. Kere

Research Programs Unit, Program for Molecular Neurology,

University of Helsinki, and Folkhälsan Institute of Genetics,

Helsinki, Finland

\section{J. Hagström}

Department of Pathology and Oral Pathology, Haartman Institute,

University of Helsinki and HUSLAB, Helsinki, Finland

S. Remes $\cdot$ J. Arola $(\triangle)$

Department of Pathology, Haartman Institute, University of Helsinki and HUSLAB, Helsinki, Finland

e-mail: johanna.t.arola@helsinki.fi
C. Söderhäll $\cdot$ J. Kere

Department of Biosciences and Nutrition, Karolinska Institutet, Huddinge, Sweden

D. Greco

Unit of Systems Toxicology, Finnish Institute of Occupational Health, Helsinki, Finland

C. Haglund

Department of Surgery, Helsinki University Hospital and University of Helsinki, Helsinki, Finland

C. Haglund

Research Programs Unit, Translational Cancer Biology, University of Helsinki, Helsinki, Finland 